\title{
KUALITAS DAN KEPUASAN PENGGUNA TERHADAP SISTEM INFORMASI AKADEMIK BERBASIS WEB
}

\author{
I Gusti Ngurah Agung Suaryana ${ }^{1}$ \\ I Gst Ayu Eka Damayanthi \\ Ni K. Lely Aryani Merkusiwati ${ }^{3}$ \\ ${ }^{1,2,3}$ Fakultas Ekonomi dan Bisnis, Universitas Udayana, Bali, Indonesia \\ email: ignasuaryana@yahoo.com
}

\begin{abstract}
ABSTRAK
Tujuan dari penelitian ini adalah untuk mengevaluasi kualitas informasi akademik berbasis web di FEB Unud dan pengaruhnya terhadap kepuasan penggguna. Pengguna adalah mahasiswa, dosen, dan staf akademik FEB Unud. Survei dilakukan terhadap persepsi mahasiswa, dosen, dan staf atas kualitas dan kepuasan mereka mengenai system informasi akademik. Kualitas sistem terdiri dari tiga elemen, yakni kualitas informasi, kualitas sistem, dan kualitas pelayanan. Kualitas atas sistem akademik berbasis web diharapkan berpengaruh terhadap kepuasan pengguna sistem. Bagi FEB Unud, hasil penelitian ini diharapkan dapat memberi umpan balik untuk pemimpin fakultas, guna mengambil langkah korektif. Bagi institusi pendidikan yang lain, hasil penelitian ini diharapkan dapat menjadi model pengembangan sistem informasi akademik.
\end{abstract}

Kata kunci: Kualitas sistem informasi, kepuasan pengguna, sistem informasi akademik, kualitas informasi.

\section{THE QUALITY AND USERS SATISFACTION OF WEB-BASED ACADEMIC INFORMATION SYSTEM \\ ABSTRACT}

The purpose of this study is to evaluate the quality of web-based academic information system in FEB Unud and its impacts to users' satisfaction. The users of this system are students, lectures, and academic staffs of FEB Unud. This study surveys the perception of students, lectures, and staffs and their satisfaction on the quality of the Academic Information System. The quality system includes three elements, namely the information quality, the system quality, and the service quality. The quality of this web-based academic information system is expected to affect the satisfaction of the users. For FEB Unud, the result of this study is expected to give the feedback for the faculty leaders in order to take further corrective measures. For other educational institutions, the study is expected to be a model of academic information system development.

Keywords: System information quality, user satisfaction, academic information system, information quality, system quality, service quality

DOI: https://doi.org/10.24843/JIAB.2016.v11.i02.p03

\section{PENDAHULUAN}

Sistem informasi akademik berbasis WEB memudahkan mahasiswa dalam mendapatkan informasi yang dibutuhkan, seperti materi kurikulum, kalender akademik, jadwal perkuliahan, dan informasi kegiatan di kampus. Mahasiswa juga dapat mendapatkan laporan hasil studi dan mengisi rencana studi secara on-line, sehingga pengisian KRS (kartu rencana studi) dapat dilakukan di mana saja dan kapan saja. Sistem informasi yang dikembangkan oleh pengelola FEB Unud dimaksudkan untuk membantu mahasiswa dalam proses belajar mengajar sehingga proses belajar mengajar menjadi efektif dan efesien. Pengelola FEB Unud akan berusaha mengembangkan sistem informasi akademik yang berkualitas untuk meningkatkan tingkat kepuasan mahasiswa, terutama dalam fungsinya untuk memberikan informasi akademik dan pengisian KRS. Sistem informasi akademik yang berkualitas dapat meningkatkan kepuasan pengguna sistem informasi.

Penelitian kualitas sistem informasi telah dilakukan oleh beberapa peneliti, seperti Negash, Ryan, dan Iqbaria (2003); Baridwan dan Hanum (2007); Yoon (2008); Mohamed, Hussin, dan Hussein (2009); dan Affani (2013). Penelitian ini mereplikasi penelitian Negash et al., (2003) serta Baridwan dan Hanum (2009), dengan menggunakan objek penelitian sistem informasi akademik berbasis WEB di FEB Unud. Penelitian dengan objek serupa telah dilakukan oleh Affani (2013) yang meneliti 
kualitas kepuasan pengguna atas penerapan kartu rencana studi (KRS) on line. Penelitian ini berbeda dengan Affani (2013) dalam karena menganalisis lebih lanjut dampak dari kualitas informasi, kualitas sistem, dan kualitas jasa terhadap kepuasan pengguna sistem informasi akademik berbasis WEB.

Penelitian ini menganalisis faktor penentu kepuasan pengguna sistem informasi akademik di FEB Unud, seperti kualitas informasi yang diberikan di WEB, kualitas sistem, dan kualitas jasa yang diberikan oleh bagian sistem informasi menurut persepsi mahasiswa. Hasil pengujian dan analisis atas faktor penentu tersebut akan menjadi bahan evaluasi atas informasi yang disajikan; sistem yang telah dikembangkan; dan jasa yang diberikan yang selama ini diberikan oleh bagian sistem informasi, untuk meningkatkan kepuasan pengguna atas sistem informasi akademik di FEB Unud.

Penelitian ini bertujuan melihat pengaruh persepsi kualitas informasi, kualitas sistem, dan pelayanan terhadap kepuasan pengguna sistem informasi akademik di Fakultas Ekonomi dan Bisnis Universitas Udayana (FEB Unud). Penelitian ini dilakukan untuk mengevaluasi efektivitas sistem informasi akademik yang dikembangkan di FEB Unud. Pengembangan sistem informasi di FEB Unud dilakukan untuk memudahkan mahasiswa dalam proses pendidikan.

Salah satu kontribusi utama bagi kesuksesan sistem informasi adalah kualitas informasi yang diperoleh dari sejumlah aplikasi yang dikembangkan. Kualitas informasi menunjukkan pengukuran output sistem informasi. Informasi yang dibutuhkan harus relevan, terpercaya dan akurat. Dimensi waktu turut mengambil andil dalam kualitas informasi (Haag; dalam Anindita et. al., 2003). Pengguna menginginkan informasi dengan tingkat kualitas yang tinggi. Kualitas atas informasi akan lebih bernilai bagi pengguna informasi tersebut. Kualitas informasi yang baik akan memberikan hasil keputusan yang baik pula. Sebaliknya kualitas informasi yang kurang baik akan memberikan keputusan yang kurang baik pula (Boone dan Kurtz; seperti dikutip Nurniah, 2005). Dengan kata lain, tingginya kualitas informasi yang dihasilkan oleh suatu sistem informasi akan memberikan kepuasan yang tinggi bagi pengguna sistem informasi tersebut. Selanjutnya, Anindita et. al., (2003) dalam penelitian mereka tidak menemukan pengaruh antara kualitas informasi dengan kepuasan pengguna. Kualitas informasi yang diukur adalah kualitas informasi sistem EDI. Bertentangan dengan hasil yang diperoleholeh Anindita et. al., (2003), Negash et. al., (2003) menemukan pengaruh antara kualitas informasi sistem pendukung berbasis WEB dengan penggunanya. Berdasarkan penjelasan diatas dapat dirumuskan hipotesis.

$\mathrm{H}_{1}$. Kualitas informasi berpengaruh terhadap kepuasan pengguna sistem informasi berbasis WEB.

Kualitas sistem adalah mengukur proses informasi melalui sistem yang digunakan,atau keterkaitan antara karakteristik sistem dengan keberhasilan implementasi sistem (Negash et. al., 2003). Oleh karena itu sistem yang akan diimplementasikan harus berkualitas, agar pengguna merasa nyaman dalam penggunaan dan pemanfaatan sistem tersebut. Sistem yang berkualitas adalah sistem yang tepat guna, memenuhi standar yang telah ditetapkan dan senantisa mengikuti perkembangan jaman serta kemajuan teknologi. Untuk menghindari adanya penolakan terhadap sistem yang dikembangkan maka kualitas sistem harus baik, dan ini akan berpengaruh pada tingkat kepuasan pengguna dari sistem tersebut (Bordnardan Hopwood, 2001).

Anindita et. al., (2003) yang meneliti faktorfaktor yang memengaruhi tingkat kepuasan pengguna sistem EDI, menunjukkan bahwa tingginya keandalan system berpengaruh terhadap tingginya kepuasan pengguna sistem EDI. Negash et. al., (2003) dalam penelitiannya pada sistem pendukung berbasis WEB terhadap kepuasan penggunaan WEB, menunjukkan kualitas sistem pendukung berbasis WEB berpengaruh terhadap penggunanya. Dari penelitianpenelitian sebelumnya, peneliti mengharapkan bahwa tingginya kulitas sistem akan meningkatkan kepuasan pengguna dari sistem tersebut. Hipotesis penelitian dapat dirumuskan sebagai berikut.

$\mathrm{H}_{2}$ : Kualitas sistem berpengaruh terhadap kepuasan pengguna sistem informasi berbasis WEB.

Dalam lingkup sistem informasi, kebutuhan pengguna terhadap sistem informasi harus dapat dideteksi dengan baik oleh perancang sistem supaya sistem yang diterapkan di dalam suatu organisasi dapat memenuhi kebutuhan penggunanya (Taniel dan Manao, 1993; dalam Nurniah, 2005). Pemenuhan kebutuhan pengguna dapat memberikan kepuasan terhadap sistem yang diterapkan. Para peneliti berpendapat bahwa kualitas (output) secara teknik memang perlu tetapi belum cukup untuk mencapai kepuasan pelanggan, karena keseluruhan kualitas jasa yang dirasakan juga termasuk mencapai fungsional kualitas dengan baik. (Kettinger dan Lee, 1994). Kulitas layanan digunakan untuk mengukur kepuasan pelanggan terhadap layanan yang diberikan 
oleh suatu sistem yang digunakan. Kettinger dan Lee (1994) menguji hubungan kualitas layanan dan kepuasan para pengguna jasa departemen sistem informasi. Hasil penelitian menunjukkan kedua dimensi kualitas jasa (relaibilitas dan empati) merupakan prediktor yang signifikan atas kepuasan pengguna jasa sistem informasi akuntansi. (Mulyadi 1999 dalam Nurniah, 2005) menemukan adanya hubungan signifikan antara kualitas jasa dan kepuasan para pengguna jasa sistem informasi. Semakin baiknya pelayanan yang diberikan staf departemen sistem informasi dalam memenuhi harapan pengguna vang terkait dengan semakin tingginya kepuasan para pengguna tersebut. Berdasarkan hasil penelitian sebelumnya, dapat dirumuskan hipotesis penelitian sebagai berikut.

$\mathrm{H}_{3}$ : Kualitas jasa berpengaruh terhadap kepuasan pengguna informasi berbasis WEB.

\section{METODE PENELITIAN}

Penelitian ini menggunakan pendekatan kuantitatif dengan metode pengumpulan data survey. Penelitian menggunakan kuesioner sebagai alat pengumpulan data utama. Langkah pertama penelitian adalah menetapkan populasi dan sampel penelitian. Populasi adalah keseluruhan obyek penelitian sebagai sumber data yang memiliki karakteristik tertentu dalam penelitian. Populasi penelitian adalah seluruh mahasiswa $\mathrm{S} 1$ aktif, dosen, dan pegawai bagian akademik di lingkungan FEB Unud. Jumlah mahasiswa S1 aktif di lingkungan FEB Unud adalah 3.311. Jumlah dosen di lingkungan FEB Unud sebesar 189 orang, dan pegawai bagian administrasi sebesar 28 orang.

Penentuan sampel penelitian menggunakan rumus Slovin agar sampel dapat mewakili populasi (Umar, 2004). Berdasarkan hasil perhitungan rumus Slovin jumlah sampel penelitian mahasiswa S1, dosen, dan pegawai bagian akademik asing-masing berjumlah 97, 53, dan 22 orang. Teknik sampling yang dipergunakan dalam penelitian ini adalah Nonprobability sampling. Nonprobability Sampling yaitu teknik pengambilan sampel yang tidak memberi kesempatan yang sama bagi setiap unsur (anggota) populasi untuk dipilih menjadi anggota sampel. (Sugiyono, 2011). Sampel dipilih dengan menggunakan teknik sampling insidental yaitu teknik penentuan sampel berdasarkan kebetulan.

Variabel Penelitian terdiri atas variabel independen dan dependen. Variabel dependen penelitian ini adalah kepuasan pengguna sistem informasi akademik berbasis WEB dan variabel independen penelitian adalah kualitas sistem, kualitas informasi, dan kualitas jasa sistem akademik berbasis WEB.

Kepuasan pengguna sistem informasi adalah pengungkapan kesusuaian antara harapan seseorang dengan hasil yang diperolehnya, dikarenakan adanyapartisipasi selama pengembangan sistem (Ives et. al., 1983). Kualitas sistem informasi akademik terdiri atas tiga variabel yaitu kualitas sistem, kualitas informasi, dan kualitas jasa (Baridwan dan Hanum 2009). Kualitas sistem mengukur proses informasi melalui sistem yang digunakan,atau keterkaitan antara karakteristik sistem dengan keberhasilan implementasi (Negash et. al., 2003). Kualitas informasi menyangkut nilai keluaran yang dihasilkan oleh satu sistem yang dirasakan oleh pengguna. Kualitas jasa adalah keandalan, kecepatan, dan keyakinan pengguna sistem sistem informasi atas pelayan yang diberikan oleh bagian sistem informasi.

Variabel independen penelitian ini antara lain kualitas sistem, kualitas informasi, dan kualitas jasa. Variabel dependen penelitian adalah kepuasan pengguna. Kualitas informasi mengukur proses informasi melalui sistem yang digunakan,atau keterkaitan antara karakteristik sistem dengan keberhasilan implementasi(Negash et. al., 2003). Kualitas informasi meliputi tiga dimensi, yaitu dimensi waktu, dimensi isi ,dan dimensi bentuk ( $\mathrm{O}^{\prime}$ Brien, 2006; Baridwan dan Hanum, 2007).

Kualitas sistem diukur dengan 7 indikator yang berasal dari 8 indikator yang dikembangkan oleh Bailey danPearson (1983) serta diterapkan oleh Baridwan dan Hanum (2007). Penelitian ini hanya memfokuskan peneltian pada pengguna WEB, sehingga satu indikator dari Bailey dan Pearson (1983) tidak dapat dipergunakan.

Kualitas Jasa meliputi 4 dimensi yaitu reliability, responssiveness, Assurances, dan empathy. Indikator dari empat dimensi ini dikembangkan dipergunakan sebelumnya oleh Baridwan dan Hanum (2007) dan Sari (2008). Kepuasan Pengguna. Kepuasan memodifikasi indikator penelitian Baridwan dan Hanum (2007). Indikator penelitian yang mengukur kepuasan pengguna meliputi 9 indikator.

Instrumen penelitian berupa kuesioner. Format kuesioner penelitian ini adalah pertanyaan-pertanyaan tertutup, yakni kemungkinan jawabannya sudah ditentukan terlebih dahulu dan responden tidak diberi kesempatan memberikan jawaban yang lain.

Skala pengukur yang digunakan dalam penelitian ini adalah skala yang dimodifikasi dengan bentuk 
pilihan ganda, dimana setiap pernyataan diberi range skor antara 1 sampai dengan 5. masingmasing adalah: STS $=$ Sangat Tidak, Setuju $\mathrm{S}=$ Setuju, TS = Tidak Setuju, SS = Sangat Setuju, N = Netral. Alat analisis pada penelitian ini adalah structural equation modeling (SEM) berbasis kovarian. Statistik inferensi bertujuan untuk menguji model dan hipotesis penelitian.

\section{HASIL DAN PEMBAHASAN}

Tabel 1 menunjukan data yang fit karena telah memenuhi semua kriteria yang dipersyaratkan. Meskipun beberapa uji, seperti signifikan probabilitas memiliki nilai kurang dari 0,05, sedangkan CMIN/ DF, GFI, AGFI, TLI, dan CFI memiliki nilai kurang dari 0,90, namun masih dapat diterima dengan kategori marginal sehingga tetap memenuhi syarat. Hal ini berarti data tersebut sesuai dengan model.

Tabel 1.

Evaluasi Kriteria Goodness of Fit Model Penelitian

\begin{tabular}{llll}
\hline Goodness of Fit Index & Cut-off Value & Hasil Uji & Keterangan \\
\hline X2-Chi Square & Diharapkan nilai lebih kecil & 2.563 & Marginal \\
Significance Probability & $\geq 0,050$ & 0,000 & Marginal \\
CMIN/DF & $\leq 2,000$ & 2,033 & Marginal \\
GFI & $\geq 0,900$ & 0,667 & Marginal \\
AGFI & $\geq 0,900$ & 0,636 & Marginal \\
TLI & $\geq 0,950$ & 0,741 & Marginal \\
CFI & $\geq 0,950$ & 0,753 & Marginal \\
RMSEA & $\leq 0,080$ & 0,075 & Baik \\
\hline
\end{tabular}

Sumber: Data diolah, 2015

Pengujian hipotesis penelitian dilakukan berdasarkan hasil analisis kausalitas antar kontruk penelitian yang disajikan pada Tabel 2. Nilai koefisien standardize regression weight antara variabel kualitas sistem dengan variabel kepuasan adalah sebesar 0,434 dengan probabilitas sebesar 0,007 atau lebih kecil daripada 0,05 . Hal ini berarti variabel kualitas sistem berpengaruh positif terhadap kepuasan pengguna sistem informasi akademik berbasis WEB.

Tabel 2.

Pengukuran Unstandardize dan Standardize Regression Weight pada Model Struktural

\begin{tabular}{lrlcrl}
\hline & Hubungan & & $\begin{array}{c}\text { standardize } \\
\text { regression } \\
\text { weight }\end{array}$ & probability & Keterangan \\
\hline Kepuasan Pengguna & $<--$ & Kualitas Sistem & 0,434 & 0,007 & H1 Diterima \\
Kepuasan Pengguna & $<-$ & Kualitas Informasi & 0,797 & 0,005 & H2 Diterima \\
Kepuasan Pengguna & $<--$ & Kualitas Jasa & 1,179 & 0,000 & H3 Diterima \\
\hline
\end{tabular}

Sumber: Data diolah, 2015

Hasil pengujian Tabel 2, mendukung hipotesis penelitian $\left(\mathrm{H}_{1}\right)$ yang menyatakan bahwa terdapat pengaruh yang signifikan kualitas sistem terhadap kepuasan pengguna sistem informasi berbasis WEB. Hasil pengujian hipotesis mendukung hipotesis penelitian bahwa kualitas sistem berpengaruh positif terhadap kepuasan pengguna informasi akademik berbasis WEB di Fakultas Ekonomi Universitas Udayana. Kualitas sistem yang telah disiapkan dengan baik dan berkualitas tinggi terbukti memeberikan kepuasan kepada pengguna sistem informasi yang terdiri atas mahasiswa, dosen, dan pegawai bagian akademik. Sistem akademik berbasis WEB yang baik, seperti sistem akademik mudah dalam pengoperasiannya, tidak menimbulkan keraguan dalam pengoperasiannya, dapat memenuhi kebutuhan pengguna sistem, mudah pengoperasiannya, dapat diakses di mana saja serta kapan saja, dan sistem cepat merespon input yang diberikan oleh pengguna sistem akan memberikan kepuasan pengguna sistem informasi akademik berbasis WEB.

Hasil penelitian ini sesuai dengan hasil penelitian sebelumnya, seperti Bordnar dan Hopwood (2001), Anindita et. al., (2003), dan Negash et. al., (2003) yang menemukan pengaruh antara kualitas informasi sistem. Hopwood (2001) dan Anindita et. al., (2003) menunjukkan bahwa tingginya keandalan sistem berpengaruh terhadap tingginya kepuasan pengguna 
sistem EDI. Negash et. al., (2003) dalam penelitiannya pada sistem pendukung berbasis WEB terhadap kepuasan pengguan WEB, menunjukkan kualitas sistem pendukung berbasis WEB berpengaruh terhadap penggunanya.

Tabel 2 menunjukan nilai koefisien standardize regression weight antara variabel kualitas informasi dengan variabel kepuasan adalah sebesar 0,797 dengan probabilitas sebesar 0,005 atau lebih kecil daripada 0,05 . Hal ini berarti variabel kualitas informasi berpengaruh positif terhadap kepuasan pengguna sistem informasi akademik berbasis WEB. Hasil pengujian ini mendukung hipotesis penelitian $\left(\mathrm{H}_{2}\right)$ yang menyatakan bahwa terdapat pengaruh yang signifikan kualitas informasi terhadap kepuasan pengguna sistem informasi berbasis WEB.

Hasil pengujian hipotesis membuktikan bahwa kualitas informasi berpengaruh terhadap kepuasan pengguna sistem informasi berbasis WEB. Informasi yang berkualitas yang dikembang dari tiga dimensi, yaitu dimensi waktu, dimensi isi, dan dimensi bentuk terbukti meningkatkan kepuasan pengguna informasi akademik berbasis WEB yang terdiri atas mahasiswa, dosen, dan pegawai. Hal ini berarti pemakai sistem informasi akademik berbasis WEB menganggap informasi yang berkualitas sangat penting sehingga dapat memuaskan pengguna sistem. Infromasi yang berkualitas, seperti informasi yang tersaji tepat waktu, uap-to-date, akurat, informasi yang relevan dengan kebutuhan pemakai, dan tersaji dalam bentuk yang menarik harus diperhatikan oleh lembaga dalam pengembangan sistem informasi. Kualitas informasi sangat penting di FEB Unud karena semua informasi yang dibutuhkan oleh mahasiswa, dosen, dan pegawai.

Hasil penelitian ini mendukung hasil penelitian sebelumnya, seperti Bordnar dan Hopwood (2001), Anindita et. al., (2003), dan Negash et. al., (2003). Kualitas atas informasi akan lebih bernilai bagi pengguna informasi tersebut. Kualitas informasi yang baik akan memberikan hasil keputusan yang baik pula. Sebaliknya kualitas informasi yang kurang baikakan memberikan keputusan yang kurang baik pula (Boone dan Kurtz; seperti dikutip Nurniah, 2005). Dengan kata lain, tingginya kualitas informasi yang dihasilkan oleh suatu sistem informasi akan memberikan kepuasan yang tinggi bagi pengguna sistem informasi tersebut.

Tabel 2 menunjukan nilai koefisien standardize regression weight antara variabel kualitas Jasa dengan variabel kepuasan adalah sebesar 1,179 dengan probabilitas sebesar 0,000 atau lebih kecil daripada 0,05 . Hal ini berarti variabel kualitas jasa staff sistem informasi berpengaruh positif terhadap kepuasan pengguna sistem informasi akademik berbasis WEB. Hasil pengujian ini mendukung hipotesis penelitian $\left(\mathrm{H}_{3}\right)$ yang menyatakan bahwa terdapat pengaruh yang signifikan kualitas jasa bagian sistem informasi terhadap kepuasan pengguna sistem informasi berbasis WEB.

Penelitian ini membukti hipotesis bahwa kualitas pelayanan berpengaruh terhadap kepuasan pengguna sistem informasi akademik. Pelayanan yang baik dari unit informasi dan komunikasi yang dibentuk di FEB Unud terbukti dapat memuaskan pengguna sistem informasi akademik yang terdiri atas mahasiswa, dosen, dan pegawai akademik di lingkungan FEB Unud. Indikator kualitas pelayanan, seperti reliability (keandalan), responsiveness (kecepatan), assurance (dipercaya), dan empathy (empati) perlu mendapat perhatian dari unit sistem informasi di FEB Unit karena telah terbukti memberikan kepuasan kepada pengguna sistem. Keandalan dari staff sistem informasi dalam melayani pengguna sistem meliputi (1) kemampuan unit sistem informasi dalam menyediakan informasi yang dibutuhkan oleh pengguna sistem informasi, (2) unit informasi dan komunikasi mampu menyediakan jasa yang telah dijanjikan, (3) unit sistem informasi dapat diandalkan dalam mengani masalah yang dihadapi oleh pengguna sistem informasi, (4) unit sistem informasi mampu menyimpan data yang dibutuhkan oleh pemakai, dan (5) unit sistem informasi telah memberikan jasa tanpa kesalahan kepada pengguna sistem informasi. Selain dimensi keandalan, unti sistem informasi perlu memperhatikan dimensi kecepatan dalam merespon kebutuhan pengguna sistem. Dimensi kecepatan respons meliputi (1) kecepatan respon unit sistem informasi dalam melayani pengguna ketika dibutuhkan, (2) kecepatan respons unit sistem informasi dalam menangani masalah yang dihadapi oleh pengguna sistem informasi, (3) unit sistem informasi menginformasikan waktu pemberian jasa kepada pengguna, dan (4) unit sistem informasi mempu memeberikan jasa ketika dibutuhkan oleh pemakai sistem informasi. Indikator dimensi assurance yang harus diperhatikan oleh unit sistem informasi dalam memberikan kepuasan kepada pengguna, antara lain unit sistem informasi seharusnya (1) memiliki pengetahuan yang luas, (2) terlatih, (3) mampu menumbuhkan rasa percaya kepada pengguna sistem informasi mengenai jasa yang dapat diberikan, dan (4) bersikap sopan. Terakhir, unit sistem informasi dan komunikasi harus memberikan empati kepada pengguna sistem 
informasi untuk memberikan kepuasan kepada pengguna sistem.

Hasil Penelitian ini mendukung hasil penelitian sebelumnya, seperti Kettinger dan Lee (1994) dan Mulyadi dalam Nurniah (2005) yang menemukan adanya hubungan signifikan antara kualitas jasa dankepuasan para pengguna jasa sistem informasi. Semakin baiknya pelayanan yang diberikan staf departemen sistem informasi dalam memenuhi harapan pengguna yang terkait dengan semakin tingginya kepuasan para pengguna tersebut.

\section{SIMPULAN}

Penelitian ini berhasil membuktikan adanya pengaruh kualitas sistem, kualitas informasi, dan kualitas pelayanan terhadap kepuasan pengguna sistem informasi berbasis WEB di FEB Unud. Semakin baik kualitas sistem, kualitas informasi, dan kualitas pelayanan akan meningkatkan kepuasan pengguna sistem informasi di FEB Unud. Kualitas sistem, kualitas informasi, dan kualitas pelayanan yang semakin baik terbukti meningkatkan kepuasan pengguna sistem informasi akademik.

Berdasarkan hasil penelitian beberapa implikasi yang dapat diberikan kepada unit informasi dan komunikasi FEB Unud. Pertama, Unit sistem informasi perlu memperhatikan faktor penentu kepuasan pengguna sistem informasi akademik berbasis WEB, seperti kualitas sistem, kualitas informasi, dan kualitas pelayanan. Kedua, hasil penelitian ini menemukan sebagian besar pengguna sistem informasi akademik berbasis WEB menilai kualitas sistem, kualitas informasi, dan kualitas pelayanan sudah baik. Hal ini perlu dipertahankan oleh unit sistem informasi, bahkan perlu ditingkatkan dalam rangka meningkatkan kepuasan pengguna sistem informasi akademik berbasis WEB.

\section{REFERENSI}

Anindita, Dyah H., Muchlasin. (2003). Faktorfaktor yang Memengaruhi Tingkat Kepuasan Pemakai Sistem EDI dan Tingkat Inovasi Pengembangan Produk Pelayanan padaPerbankan Jakarta. Simposium Nasional Akuntansi VI.

Bailey, J. E., dan Pearson, S. W. 1983. Development of a Tool for Measuring and AnalizingComputer User Satisfaction". Management Sciene. 29(5), 530545

Baridwan, Zaki. (1985). Sistem Informasi Akuntansi. YKPN. Yogyakarta.
Baridwan, Z., \& Hanum, L. (2007). Kualitas dan Efektifitas Sistem Informasi Berbasis Komputer. TEMA. 8(2), 153-171.

Bodnar, George H., \& William S. Hopwood. (2001). Accounting Information System. Eight Edition, Prentice Hall Intemasional.

Cooper, Donald R., \& C. William Emory. (1995). Business Research Methods, fifth edition, Chicago, Irwin.

Dini, Muchlasin, Sosian. (2003). DeterminanDeterminan Penentu Keberhasilan Penciptaan suatu Pusat Informasi pada Sektor Jasa Perbankan. Simposium Nasional Akuntansi VI.

Doll, W.J., Xia, W., \& Torkzadeh, G. (1994). A Confirmatory Factor Analysis of the End-User Computing Satisfaction Instrument. MIS Quarterly, 18(4), 453-461.

Feny, \& Devie. (2003). Kualitas Jasa Sistem Informasi dan Kepuasan Para Pengguna Sistem Informasi. Simposium Nasional Akuntansi VI.

Hadiati, Sri. 2003. Analisis Pengarah Kualitas Pelayanan Terhadap Kepuasan Nasabah Bank Widyana Malang. Kompak, 8, 298-311.

Mohamed, N., Hussin, H., \& Hussein, R. (2007). Measuring Users' Satisfaction with Malaysia's Electronic Government Systems. Electronic Journal of e-Government,7(3), 283-294. International Islamic University Malaysia, Kuala Lumpur, Malaysia.

Kettinger, W. J., \& Lee, C.C. (1994). Perceived Service Quality and User Satisfaction with theInformation System Function. Decision Science, 25(5), 737-766.

Kotler, Philip. 2000. Manajemen Pemasaran (Terjemahan). Prentice H ill International.

Li Xiao, \& Subhasish Dasgupta. (2002). Measurement of User Satisfaction with WEB -Based Information System: An Empirical Study. Eight America Conference on Information System.

Mulyadi, Rusma. (1999). Kualitas Jasa Sistem Informasi dan Kepuasan Para Penggunanya. Jumal Bisnis dan Akuntnasi. 1(2), 120-133.

McLeod Jr, Raymond. (2001). Management Information System. Eight edition. Prentice Hall Int. New Jersey.

Negash, Terry Ryan, \& Magid Igbaria. (2003). Quality and Effectiveness in WEB-Based Customer Support Systems, Information \& Management, 40, 757-768.

Nurniah. (2005). Kualitas dan Keefektifan Sistem Layanan Konsumen Mobile Banking (Studi 
Kasus BCA Cabang Malang), Tesis. Program Pasca Sarjana, Universitas Brawijaya, Malang. O’Brien, James A. (1993). Management Information System: A managerial and User Perspective. Second Edition. McGraw-Hill Intemasional, United States of America.

O'Brien, James A., \& Goerge M. Marakus. (2006). Management Information System. Seventh Edition. McGraw-Hill Intemasional, United States of America.

Pontoh, Grace T., \& Nur Indriantoro. (1998). Peranan Sistem Informasi dan Perencanaan Sistem Informasi dalam Organisasi : Suatu Studi Empiris. Kelola. 8(20), 111-134

Rokhman, Ali, M.S Idrus, Kertahadi. (1998). FaktorFaktor yang Berhubungan dengan Keberhasilan Penerapan Sistem Informasi Berbasis Komputer pada Perusahaan Media Massa Cetak di Propinsi Daerah Jawa Timur. Wacana. (1) 2.

Sari, Y. (2008). Pengaruh Kualitas Jasa Sistem Informasi Terhadap Kepuasan Pengguna Sistem Informasi. STIE Perbanas Surabaya.

Sugiyono. (2011). Metode Penelitian Kuantitatif, Kualitatif dan $R \& D$. Bandung:Alfabeta

Tjiptono, Fandy. (2000). Manajemen Jasa. Penerbit Andi. Yogyakarta

Tjiptono, Fandy dan Gregorius Chandra. (2005). Service, Quality Satisfaction. Penerbit Andi, Yogyakarta

Yoon, S (2008). Effects of e-Service Quality on Perceived Value, Satisfaction, and Reuse Intentions in Online Hotel Booking: Evaluating Hotel-owned and OTAs'WEB sites. The School of Hospitality Business Michigan State University 